\title{
MACRO-PRUDENTIAL POLICY: ESSENCE AND MEANING (For sustainability of financial system)
}

\section{ELISO BERIDZE}

PhD student

Ivane Javakhishvili Tbilisis State University, Georgia

eberidze@gmail.com https://doi.org/10.35945/gb.2018.06.021

\section{KEY WORDS: FINANCIAL SYSTEM; FINANCIAL CRISIS; MACROPRUDENTIALL POLICY; SUPERVISORY POLICY;} CREDIT CYCLE AND SYSTEMATIC RISKS

The financial crisis posed significant challenges to the existing structure of the financial system and its supervisory policy. States have taken a number of measures around the world to counter the negative effects of the financial crisis on the one hand and on the other hand they started the long-term process of reforming supervisory policy of the financial sector. The reform aimed at eliminating shortcomings previously existing in practice and implementing measures, as a result of which a more robust and sustainable financial system should be formed. (e.g. Bank for International Settlements (BIS), 2011, 81 $1^{\text {st }}$ Annual Report, V. Financial Regulatory Reform: Accomplishments, Pitfalls, Prospects).

Against the background of all this, in recent years, policy makers and macroeconomists focus their close attention on the macroeconomic analysis of financial regulation methods (e.g. Blanchard, Dell 'Ariccia \& Maoro 2012, 2013). Debates are mainly focused on macro-prudential instruments and their effective use of ways, the relationship between macro-prudential and monetary policies and the difficulties associated with all this.

Macro-prudential policy implies monitoring, evaluation and carrying out such a supervisory policy of financial stability which will be aimed at eradicating systemic risks and neutralizing pro-cyclic nature of the financial sector (growing to the cycle direction, pro-cyclical). The macro-prudential policy is of a preventive nature and its goal is to increase the financial system's endurance against exogenous shocks and to limit the creation of financial imbalance on the assets and credits market, which is one of the key features of the financial crises. In order to reduce the imbalance in the financial market, a particular importance is attached to the implementation of countercyclical policy and the impediments to the risks emergence in this regard.

One of the issues of macro-prudential policy, the importance of which, the financial crisis clearly demonstrated, is the necessity of systemic approach in supervisory policy. Inadequate assessment of systemic risks was one of the causes of the financial crisis. Banks regulatory bodies, as a rule, were focused on the so-called "idiosyncratic risks" - the risks associated with a specific bank. Systemic risks pose a threat to the entire financial system and not just a single institution, isolated.

Systemic risks can be divided into several categories.
The first, these are the exogenous shocks which include the economic downturn, foreign shocks and others. This kind of shocks implies an independent event happening independently from us. The second is so-called "contagious effects," which is due to the high integration of the financial sector internationally. The third category is the accumulation of financial imbalance that is the risk of endogenous nature and is often collected by market participants, their regulators, central banks and government. An example of this is also the global financial crisis when the reduced interest rates on monetary policy on one hand and the irrational financial supervisory policy on the other hand encouraged the rise of real estate prices.

According to the nature of systemic risk, the approaches are different which in each case are confronted by macroprudential policy. If towards the exogenous shocks the macro-prudential policy should control and increase the endurance of the financial system, their prior prevention of risks of financial imbalance should be prevented. After the financial crisis, great attention was paid to this direction and a number of instruments started to be introduced in supervisory policy aimed at eradicating systemic risks. The main source of systemic risks is the pro-cyclical nature of the financial sector.

The basis for the financial system's pro-cyclicity in the market is created by asymmetry of information. In particular, when the economic situation is deteriorated (during recession) the mortgage assets prices (the real estate, the capital of the firms), decrease and the balance sheet of the firms worsens, consequently, even profitable investment projects are hardly financed, and when the economic conditions are improved (in the phase of economic growth) the mortgage assets prices increase, firms easily find finances and this further increases the economic activity. Such a connection of economic and financial cycles is called "financial acceleration." It should be noted that, besides financial acceleration, there are other factors that make the financial sector pro-cyclical (e.g. Borio and others 2001; Gertler, Kiotaki 2010; Rajan 2005). Through the modern researches it is considered that an additional pro-cyclical source is an inadequate response of the participants of financial market to the changes of economic risks. Various factors often indicate that during 
the economic boom risks are assessed improperly and during recession- exaggeratedly.

One of the sources that makes the financial sector pro-cyclical is also the financial supervision policy, which is working actively after the crisis for its eradication. Specifically, the practice of regulating the possible loss of loans indicates that the possible loss of reserve is linked to de-facto delays in the loans service. Accordingly, in the phase of the economic cycle upturn, the bank needs a small reserve of possible losses and in the downturn phase of the cycle (period of economic stagnation) when poor quality loans are revealed, the reserve of possible losses grows. Also, according to Basel $\mathrm{II}^{1}$, the requirements for ensuring capital adequacy were distinguished with the approach of pro-cyclical nature.

The capital requirements are mitigated during the credit cycle boom, which further exacerbates the noted process. During the downturn of the credit cycle, when the lending is reduced, the capital requirements are tightened, which further limits the lending and consequently hampers the economy.

Regulation of financial sector in the area of macroprudential policy becomes depended on the business cycle. Specifically, reservation norms for capital adequacy and possible loss of loans gain an opposite nature of the cycle. The noted idea implies that the capital requirements should be tightened during the credit cycle boom to restrict the credit portfolio's excessive growth and the demands to be weakened during the period of downturn in order to encourage lending growth. Therefore, it ensures stabilizing function. In the case of regulating systemic risks with macro-prudential supervision policy, analytical methods are needed to assess the optimal level of supervisory norms. In particular, how to calculate and evaluate the credit or business cycles, how to measure the basic tools of macro-prudential policy.

It should be noted that the tools of macro-prudential policy are quite diverse; however, they are divided into two main categories. The first category includes the tools that have a time dimension. The tools of this category are designed to eliminate the pro-cyclicity of financial system. The second, these are the tools oriented to the limitation of risks distribution (in the specific period of time). Out of the tools with time dimension, the most widely used instruments are the Countercyclical Capital Buffer, Loan-to-Value (the ratio of Ioan-to-value), Debt-to-Income (Debt Service Burden) and Dynamic Provisioning (Dynamic Rule of Reserves to Possible Losses). The use of instruments oriented to the limitation of risks distribution implies additional, capital and liquid assets requirement for Systemically Important Financial Institute as well as restrictions on non-basic and non-core activities of the

\footnotetext{
1 Banking Supervision Basel Committee develops and defines the best practice of banking supervision and legislation, which provides recommendations to the regulatory authorities of the world's financial sector. Basel II is a second generation agreement that has already been replaced by Basel III in 2010-2011.
}

bank and others. The macro-prudential policy pays special attention to the banks with systemic importance, which are sufficiently big for the government to make them bankrupt (too big to fail). In this case, additional safety norms are required that the financial system should not be threatened by one of the bank and taxpayers shouldn't be burdened.

The goal of the countercyclical buffer is to achieve the main goal of macro-prudential policy by utilizing a capital buffer and restricting the banking sector from the growth of excessive lending (which is often associated with the creation of system risk (e.g. Drehmann, Claudio Borio, Tsatsaronis, 2011; Drehmann and others, 2010), while the other will prepare after the boom to endure losses in the phase of downturn. In particular, the capital buffer created within the instrument ensures that the banking sector has enough capital to avoid constraints on lending to the economy in the period of stress after the surplus increase. The latter is an important factor for macroeconomic stability, which is an important factor in the reduction of the additional financial losses in financial sector. ${ }^{2}$

Besides, the countercyclical capital buffer serves the protection of the banking sector during stress, it also performs a constraining function of the systemic risks accumulation (lean against the wind). In particular, using a capital buffer can increase lending costs and reduce the demand when it shows that the rate of lending is higher compared to the past trends. However, it should be noted that the hindering function of excessive lending for the countercapital buffer is not the main function, its main function is to increase sustainability in possible stress conditions.

For the use of these instruments, the relevant authorized institution is guided by international practice, ${ }^{3}$ which states that it uses all the information available at its discretion to properly assess the systemic risks and determine the additional amount of capital required for the banks. According to Basel's recommendations, for determination of capital buffer's specific mark it is used the analysis of the ratio of loans to the private sector to GDP (credit-to-GDP gap). In particular, how the credit-to-GDP gap is deviated from its historical trend, indicating the level of potentially systemic risk and therefore the capital buffer is determined based on it. The noted indicator historically describes the systemic risks accumulation well (e.g. Drehmann and others, 2010).

In the sense of macro-prudential policy, the following instruments are loan-to-value (LTV) and Debt-to-Income (DTI) coefficient. Many countries of the world widely use to set maximum limits for LTV indicator. This limitation aims to reduce systemic risks, which accompany the emergence of real estate prices bubble. In particular, the establishment of the upper limit of LTV ensures that the volume of the loan is less

\footnotetext{
2 For example, BIS, 2010 (Guidelines for National Authorities Operating the Countercyclical Capital Buffer).

32010 Guidelines for National Authorities Operating the Countercyclical Capital Buffer.
} 
compared with the price of mortgage real estate, which limits speculative growth of real estate prices and reduces the effect of financial acceleration (e.g. Crowe, Dell'Aricccia, Igan, Rabanal, 2011; Drehmann, Juselius, 2012). In some cases, regulation of LTV is discriminatory according to the real estate purpose (e.g. Strict rules are established in the case of acquisition of property for commercial and speculative purposes, while the preferential conditions are applied in case of the purchase of residential property. In practice, regulation of the DTI coefficient is used along with LTV. The latter implies that the net disbursement of the monthly service of the borrower must not exceed the established limit with respect to income. ${ }^{4}$

Dynamic Provisioning is also one of the widespread macro-prudential tools that had been introduced into Spain for the first time before the global financial crisis (for example, Saurina, 2009), and after the financial crisis, it has gained special popularity and has been implemented in many countries around the world. The use of Dynamic Provisioning is aimed at equal distribution of credit losses to the banking system by credit cycle. In particular, Dynamic Provisioning provides the establishment of reserve buffer for the bank during the credit cycle boom when the quality of loans with standard criteria is good and small losses are expected. Consequently, Dynamic Provisioning promotes the stability of the marginal cost of loan losses in various phases of credit cycle. Dynamic Provisioning and the countercyclical capital buffer complement each other for macro-prudential purposes, as a reserve of losses is designed to cover the expected credit losses, and the capital buffer- unexpected losses (e.g. Wezel, Chan-Lau \& Columbia, 2012).

Macro-prudential policy, in addition to neutralizing the credit cycle and systemic risks associated with it, also pays particular attention to neutralizing risks, and also pays considerable attention to eliminating possible spread of risks from one bank to another one in case of risks distribution and stress. In particular, in the wake of the global crisis, Lehman Brothers' bankruptcy in September 2008 clearly demonstrated negative externalities that are linked to the bankruptcy of the systemic bank globally. In addition, financial institutions, which are systematically significant in terms of their size, complexity, interconnection with other institutions and hard replacement in the global arena, are well aware of the dire consequences of their bankruptcy for the general economic environment, expecting that the government will not allow their bankruptcy (too big to fail) and carry a certain state guarantee. This factor generates the risk of moral hazard and increases the tendency towards their risks, gives privileges to them and creates a non-competitive environment. Due to the noted external impacts, the rational behavior of the financial institution,

\footnotetext{
${ }^{4}$ For detailed review of macro-prudential instruments and analysis of their effectiveness in the case of various countries see Lim and others, 2011.
}

with the goal of getting maximum benefit, can be sharply different from the public interest that ultimately increases the likelihood of a future crisis, and therefore the burden of taxpayers (e.g. BIS, 2013, Global systematically important banks, updated assessment methodology and the higher loss absorbency requirement).

In order to solve the above noted problem, the microprudential policy aims to reduce the probability of systemic banks' bankruptcy and in case of bankruptcy limits the negative effects for the system.

In particular, in November 2011, the Basel Committee issued a basic framework ${ }^{5}$ of the methodology, which states that systemic financial institutions should be identified and provided with an additional capital buffer to increase sustainability with respect to losses. The Basel Committee also focuses on the necessity of the effectiveness of financial institution's bankruptcy mechanism. In case of necessity the mechanism should ensure the institution's bankruptcy and direct the procedure is such a way that it doesn't to lead to paralysis of the whole financial system and / or the burden of taxpayers (e.g. Financial Stability Board, 2011), Key Attributes of Effective Resolution Regimes for Financial Stability.

The financial macro-prudential regulation policy is crucial for prevention and overcoming crises, although it may not be enough. After the crisis, the economists paid special attention to the role of countercyclical fiscal and monetary policy for financial stability (e.g. Blachard, Dell 'Ariccia \& Mario 2012, 2013). Specifically, the countercyclical fiscal policy is aimed at stabilizing the economic cycle, reducing credit losses during recession, also hindering the accumulation of systemic risks in cycle boom phase.

The monetary policy by its content is the opposite to the cycle and its main objectives, stability of prices and stabilization of economic growth in the long run promotes the stability of financial sector. However, in recent period a number of researches has been devoted to the study of the interaction of monetary and financial supervisory policies (e.g. Borio 2014, Blanchard, Dell 'Ariccia \& Mario 2012, 2013), which clearly demonstrated that there may also be conflict situations where policy implementers have to choose between different goals. Also, the financial crisis demonstrated that when determining monetary policy, attention should be paid to the economic cycle analysis in a wide range of context, including the dynamics of the prices of financial assets in order to decrease the possible emergence of price bubble. Thus, at the contemporary stage (in the conditions of globalization), when financial assets are ripped off the real sector of the economy it is necessary to implement the macro-prudential policy in order to minimize risks in the financial sector of the economy.

\footnotetext{
Basel Committee on Banking Supervision, 2013, "Global systematically important banks: updated aassessment methodology and the higher loss absorbency requirement".
} 


\section{REFERENCES:}

1. Bank for International Settlements (BIS), 2011, $81^{\text {st }}$ Annual Report, V. Financial Regulatory Reform: Accomplishments, Pitfalls, Prospects;

2. Oliver Blanchard, Dell' Ariccia \& Maoro. 2012, 2013;

3. Claudio Borio, Craig Furfine and Philip Lowe. Procyclicality of the Financial System and Financial Stability: issues and policy options (2001); Mark Getler, Nobuhiro Kiotaki. Financial Intermediation and Credit Policy in Business Cycle Analysis (2010); Raghuram Rajan (2005);

4. Crow, Dell'Ariccia, Igan, Rabanal,2011; Drehman, Juselius, 2012;

5. Jesus Saurina, (BIS) papers \#1, 2009;

6. Torsten Wezel, Jorge A. Chan-Lau \& Francesco Columbia. Dynamic Loan Loss Provisioning: Simulations on Effectiveness and Guide to Implementation. IMF Working Papers.(2012);

7. (BIS), 2013, Global systematically important banks: updated assessment methodology and the higher loss absorbency requirement;

8. Financial Stability Board (2011). Key Attributes of Effective Resolution Regimes for Financial Stability;

9. Claudio Borio, Monetary policy and financial stability: What role in prevention and recovery. BIS working paper (2014); Olivier Blanchard, Dell’ Ariccia \& Mario. Rethinking Macroeconomic Policy. IMF Staff Position (2012, 2013). 


\section{MACRO-PRUDENTIAL POLICY: ESSENCE AND MEANING}

\section{For sustainability of financial system}

ELISO BERIDZE

https://doi.org/10.35945/gb.2018.06.021

PhD Student

Ivane Javakhishvili Tbilisi State University, Georgia

eberidze@gmail.com

KEYWORD: MACRO-PRUdENTIAL POLICY, FINANCIAL STABILITY, NEUTRALIZING PRO-CYCLIC NATURE

\section{SUMMARY}

Macro-prudential policy implies monitoring, evaluation and carrying out such a supervisory policy of financial stability which will be aimed at eradicating systemic risks and neutralizing pro-cyclic nature of the financial sector (growing to the cycle direction, pro-cyclical). To do this, it is necessary to carry out the supervisory policy: risk assessment; analysis of the activities of banking institutions and preparation of recommendations. Systemic risks include: exogenous shocks (economic fall, external shock, etc.), the second, so-called "contagious shocks" (contagion) that are due to the high integration of the financial sector internationally; the third category is the accumulation of financial imbalance that is the risk of endogenous nature and is often collected by the support of market participants.

Against the background of the global crisis, Lehman Brothers' bankruptcy in September 2009 clearly demonstrated those negative externalities which are linked to the bankruptcy of the systemic bank globally. Consequently, the macroprudential policy aims to reduce the probability of system banks' bankruptcy and in case of bankruptcy to limit the system's adverse effect. However, it is important to adequately implement the countercyclical fiscal and monetary policy. 